\title{
Danube Salmon (Hucho hucho) in Central and South Eastern Europe: A Review for the Development of an International Program for the Rehabilitation and Conservation of Danube Salmon Populations
}

\author{
Andrada IHUȚ ${ }^{1)}$, Andreas ZITEK ${ }^{2)}$, Steven WEISS ${ }^{3)}$, Clemens RATSCHAN ${ }^{4)}$, Georg HOLZER $^{5}$, \\ Thomas KAUFMANN ${ }^{6}$, Daniel COCAN ${ }^{1}$, Radu CONSTANTINESCU ${ }^{1)}$, Vioara MIREŞAN ${ }^{* 1)}$ \\ 1) Faculty of Animal Science and Biotechnologies, University of Agricultural Sciences and Veterinary \\ Medicine Cluj-Napoca, Romania \\ ${ }^{2)}$ Department of Chemistry, VIRIS Laboratory for Analytical Ecogeochemistry, University of Natural \\ Resources and Life Sciences Vienna, Austria; andreas.zitek@ecoscience.at \\ 3) Institute of Zoology, Karl-Franzens University Graz, Austria; steven.weiss@uni-graz.at \\ 4) ezb / TB Zauner GmbH, Technical Office for Applied Aquatic Ecology, Fisheries, Environmental \\ Engineering, Austria; ratschan@ezb-fluss.at \\ 5) Engineering office for landscape planning and landscape management, Austria; holzer.georg@chello. \\ at \\ 6) Freiwasser, Association for Ecology, Environmental Engineering, Austria; kaufmann@freiwasser.at \\ *Corresponding author, email: vmiresan@yahoo.com
}

Bulletin UASVM Animal Science and Biotechnologies 71(2) / 2014,

Print ISSN 1843-5262; Electronic ISSN 1843-536X

DOI:10.15835/buasvmcn-asb:10815

\begin{abstract}
Danube salmon Hucho hucho (L.), known as one of the world's largest salmonids, is among the most endangered fish species inhabiting the Danube basin of Central Europe. It is classified as endangered (EN) by the IUCN due to its very low abundance and continual decline. Historically, the natural distribution range of the Danube salmon included drainages in Austria, Bosnia-Herzegovina, Montenegro, north-western Croatia, Czech Republic, Germany, Poland, Romania, Serbia, Slovakia, Slovenia and western Ukraine. Currently, Danube salmon populations are fragmented within the Danube drainage, with many being supported by artificial reproduction and stocking programs. It is not yet possible to report that this species is safe from extinction in the wild. As a starting point to develop a sustainable conservation program, this manuscript provides a review of the current biological knowledge on Danube salmon existing in the different countries within the species distribution range in Central and South Eastern Europe.
\end{abstract}

Keywords: biology, conservation, Danube salmon, genetics, habitat, reproduction.

\section{INTRODUCTION}

Danube Salmon is one of the four species of the genus Hucho and is an endemic flagship species inhabiting the Danube watershed. Unfortunately its current status in Europe is critical, with populations continuously decreasing and only existing at low abundances (Holčík, 1988). Excessive anthropogenic impacts like habitat destruction, irresponsible deforestation, pollution, poaching and dam construction, have led to significant reductions in population abundances (Cristea, 2007; Geist et al., 2009). Today this species is found in smaller and isolated areas, with negative consequences for both demographic and genetic stability (Alvarez and Nicieza, 2003; Araki et al., 2007; Fleming and Petersson, 2001; Fraser, 2008; Geist et al., 2009; Weiss et al., 2011). According to IUCN criteria (IUCN 2014) and Bern Convention Appendix III and also Annexes II and $\mathrm{V}$ of the EU Habitat Directive huchen is listed as 
an endangered species. Therefore integrated approaches are strongly needed for the effective rehabilitation and conservation of Danube salmon populations (Schmutz et al., 2002). As a starting point to develop such an international program for rehabilitation and conservation of the Danube salmon in its full distribution range, this review summarizes information on its overall status, biology, habitat requirements, reproduction cycle and genetic structure.

Common names: Huchen and "Donaulachs" in Austria and Germany; hlavatka obecna, vaszka and gadovica in (Czech Republic, Slovakia); Danube salmon in England; sarmon du Danube in France; glowacica in Poland; lostriţă, bală, puică and lostucă in Romania; huco and huhoszemling in Hungary; mladica and ljepolica in Bosnia-Herzegovina and Serbia; sulec in Slovenia, according to (Berg, 1947; Decei, 2001; Ivaska, 1951; Nowicki, 1889; Smolian, 1920).

Danube huchen status. Historically, the natural distribution range of the Danube salmon included drainages in Austria, Bosnia-Herzegovina, Montenegro, north-western Croatia, Czech Republic, Germany (Bavaria and BadenWürttemberg), Poland, Romania, Serbia, Slovakia, Slovenia and western Ukraine (Witkowski et al. 2013b). Currently, Danube salmon populations are increasingly fragmented, with some populations still showing sufficient self-reproduction (e.g. in rivers Pielach and Mur in Austria and in some rivers in Montenegro), but often stocking occurs with some populations being dependent on artificial reproduction and stocking programs. Presently, the huchen occurs in isolated populations in Austria, Germany, Slovenia, Croatia, Bosnia and Herzegovina, Serbia, Montenegro, Romania, Hungary, Ukraine, Slovakia, the Czech Republic, and Poland (Freyhof and Kottelat, 2008). In the latter two countries, huchen occurrence is the result of introducing the species to several rivers in the Baltic Sea and North Sea drainage basins outside of their historical range (Hanel et al., 2013; Witkowski et al., 2013a).

Huchen is reported in the Appendix III of the Bern Convention on the Conservation of European Wildlife and Natural Habitats and Annexes II (designated as Sites of Community Importance must be protected under the Natura 2000 Network and the sites managed in accordance with the ecological requirements of the species) and V (All
Member States shall take measures to maintain them in a favourable conservation status in their territory) of the EU Habitat Directive.

In Austria the largest population of approximately 1,500 adult huchen is existing in a 270$\mathrm{km}$ segment of the Mur River, however the Mur population has significantly declined over the last twenty years (Schmutz et al. 2011). In various areas of Austria, the smallest river segments that huchen historically inhabited are described as being from 5 to $10 \mathrm{~m}$ in width with discharges ranging from 0.5 to $2 \mathrm{~m}^{3} \mathrm{~s}^{-1}$ (Ratschan, 2012). Currently self-sustaining populations of Danube huchen inhabit less than $10 \%$ of its former range in Austria, and in many rivers huchen occur only due to stocking programs (Ratschan and Zauner, 2012; Ratschan, 2014; Schmutz et al., 2002).

In Bosnia and Herzegovina the populations of huchen were recently documented in all rivers according to data from 2000 to 2012 with exception of the river Bosna (which is quite polluted). Huchen was never listed in the IUCN Red Book of freshwater fishes for this country, but since it is endangered in other parts of its distribution area, protection, conservation, and enhancement measures must be undertaken throughout the area in which this fish occurs (Muhamedagić and Habibović, 2013).

Huchen inhabits rivers in north-western Croatia, which are direct or indirect tributaries of the Danube River, namely, the Drava and Sava rivers in their upper courses, as well as the Kupa, Mrežnica, Dobra, and Una rivers (Mrakovčić et al., 2006).

Occurrence of huchen in Czech Republic is presently confirmed in some sections of the Labe, Oder and Morava river basins; unfortunately all populations are sustained through stocking material obtained through artificial reproduction (Hanel et al., 2013).

The huchen is also endangered in Bavaria, southern Germany, with some small populations still persisting (Geist et al., 2009). The historic range in the Danube system reached upstream into the state of Baden-Württemberg, where presently huchen only exist in small numbers (Matzinger, 2012).

The Danube huchen's natural area of occurrence in Poland includes the Czadeczka River, a tributary of the Kysuea River, and the Czarna Orawa and its tributaries (Witkowski et al., 2013a). 
Because of widespread poaching in the Czarna Orawa drainage basin and industrial pollution in the Kysuey system, the species was extirpated from its natural range in this region in the early 1950s (Witkowski et al., 2003; Witkowski et al., 2013a). To compensate for this loss and as a precaution measurement hatchery-reared huchen were introduced into a number of rivers outside their natural distribution range in the Vistula and Oder river basins (Witkowski et al., 2013b). As a result of these efforts, there are self-sustaining populations of Huchen found in the Poprad, Dunajec, and San rivers (Witkowski et al., 2013b).

Huchen in Romania are currently found in the Vişeu, Tisa, and Bistriţa rivers (the latter from Bicaz reservoir to Vatra Dornei) including sporadic appearance in tributaries of these rivers during spawning, while historically there were also found in the rivers Mureș, Cerna, Dunăre, Jiu, Olt, Lotru, Argeş, Târgului, Crişuri, Someşuri, Strei, Timiș, Lady, Buzău, Moldova Suceava and Siret (Bănărescu, 1964; Cristea, 2007). Being declared as a natural monument in Romania, the fishing of H. hucho, even recreational fishing, is prohibited by law (Annex 1 of the order no. 642 of 15 July 2005 on the establishment of protective measures for some fish species with economic and environmental value). Captive breeding is practiced at Brădişor farm, Vâlcea. However, not enough juveniles for stocking programs are produced. In Romania there is little information regarding the natural distribution of the huchen, as current studies are few and fragmentary (Bănăduc et al., 2008).

In Serbia the main river inhabited by huchen is the Drina and its tributaries. This river is 346 $\mathrm{km}$ long with an average discharge of $395 \mathrm{~m}^{3} \mathrm{~s}^{-1}$, $220 \mathrm{~km}$ of which flow through Serbia (MijovićMagdić, 2007).

The distribution area of huchen in Slovenia includes some rivers of the Sava River drainage basin (Ivanc, 2012) such as Sava Bohinjka, Sava, Ljubljanica, Sora, Mirna, Drava, Krka, and Kolpa rivers and their tributaries (Witkowski et al., 2013b). It is estimated that huchen currently inhabit 39\% of river kilometers in which it previously occurred (Bertok, 2010; Zabric et al., 2003).

The area of occurrence of huchen in Slovakia has changed significantly (Holčík, 1990; Košeo, 2012). It occurs in the Danube, Váh, Orava, Turiec, Kysuca and Hron rivers and it was introduced into the Poprad, Dunajec and Hornád rivers (Andreji and Stráňai, 2013; Košeo, 2012; Witkowski et al., 2013b). It appears that Danube huchen has recently fallen slightly out of favor with local researchers (Witkowski et al., 2013b). The average quantities of this fish caught by recreational fishers in recent years has been about 100 individuals annually (Krajč et al. 2012), which is a figure that is slightly higher than that in the 1979-1989 period (Holčík, 1990).

Historically, in Ukraine, the Danube salmon was found throughout river Tisa beginning at the confluence of the White and the Black Tisa and in nearly all its tributaries as well as in the Prut and Cheremosh rivers (Staff, 1950; Witkowski et al., 2013b), but occurrence in the Prut basin has not been confirmed (Mateleshko and Potish, 2011). Now it occurs in a $170 \mathrm{~km}$ long reach of the Tisa River along with several tributaries including the Teresva, Rika, and Terebla (Witkowski et al., 2013b). Huchen spawning grounds are found in the Tisa, Black Tisa, and Shopurka rivers, but the primary spawning grounds are located in the Teresva River and its tributaries the Luzhanka, Krasna, Mokryanka, and Brusturynka rivers (Velykopolskiy and Mruk 2012).

Biology. Danube huchen is a long lived fish species reaching more than 20 years of age in the wild (Kottelat and Freyhof, 2007). The oldest huchen thus far determined in the wild is 20+ years from the Dráva River (Pavlík, 1998; Schulz, 1985), but huchen can also reach ages of over 25 in captivity; Andreji and Stráňai (2013) found a 24 year old individual among those examined from the Príbovce farm. The huchen body is fusiform, almost cylindrical, covered with small cycloid scales and protected with an abundant layer of mucus. Juveniles have a grey-green coloration and as they get older and longer than 75-80 cm the coloration changes into a rusty hue with metallic iridescence (Decei, 2001). The lateral line is almost rectilinear with $180-200$ scales, D II-VI 8-14, A I-VI 7-11, Sp. br. 9-19, pyloric caeca 138284, vertebrae 60-72 (Holčík, 1988). The head is long and flattened dorso-ventrally and the muzzle is tapered and sharp with a big mouth that has a gape opening back until the middle of the eye. The vomer is massive and shorter than in other salmonids, and forms a continuous, horseshoeshaped band with the palatal teeth (Holčík, 1995). It has strong and sharp teeth, positioned aboral 
and extending on to the tongue, which has 6-8 teeth on each side; the mandibular branch has 1820 teeth and there are also 13-15 teeth on upper jaw (Bud et al., 2010).

As larvae and juveniles they primarily consume benthic invertebrates and insect larvae, with their diet shifting primarily to fish as they attain lengths of 50-98 mm (Augustyn et al., 1998; Holč́k, 1990; Šubjak, 2013; Witkowski et al., 2013b). If sufficiently small fish larvae are available (e.g. from early spawning cyprinids) they can start to feed on them from the beginning of exogenous feeding.

Huchen is not a selective predator and its diet features the most numerous available fish in a given river or in a given river reach (Bastl and Holčík, 1968; Witkowski et al., 1984; Holčík, 1990; Subjak, 2013). Also, prey size can vary considerably. While prey size typically lies between 15 and $30 \%$ of their own body length, in rare cases fish up to about $50 \%$ can be swallowed. Subjak (2013) caught a huchen from the Orava River (TL $104 \mathrm{~cm}, \mathrm{BW} 10.5 \mathrm{~kg}$ ) which had preyed on a chub Squalius cephalus (TL $50 \mathrm{~cm}$, BW $1.8 \mathrm{~kg}$ ) that was $48 \%$ of its own body length. Danube huchen grows faster than the other species of salmonids early in its life cycle due to the early beginning of predatory feeding (Bastl and Kirka, 1958). In natural habitats this species grows more rapidly than in farms (Andreji and Stráňai, 2013), and may reach $25 \mathrm{~cm}$ TL at the age of one year and $150 \mathrm{~g}$, while in the second year its length is about $40 \mathrm{~cm}$ and its weight is approx. 500 g (Păsărin, 2007). In the third year of life huchen may reach $600 \mathrm{~g}-1.5$ $\mathrm{kg}$ and $50-60 \mathrm{~cm} \mathrm{TL}$, with $1.5-3.3 \mathrm{~kg}$ in the fourth year (Decei, 2001), attaining a maximum length of over $1.8 \mathrm{~m}-2 \mathrm{~m}$ TL and weight of over $70-100 \mathrm{~kg}$ (Holčík, 1990, 1995; Ivaska, 1951; Mikavica and Savić, 1999). The female may be much bigger than the male, Esteve et al. (2013) observed a spawning pair in the Pielach river, with estimated sizes of between 90 and $100 \mathrm{~cm}$ for the female and 75 and $85 \mathrm{~cm}$ for the male; also in the Mur River a female with 80 to $90 \mathrm{~cm}$ and a male of only 50 to $60 \mathrm{~cm}$ were observed.

Habitat. The natural habitat of the huchen can be quite variable throughout the range of the species. In river systems without barriers, seasonally different habitats can be used, e.g. for overwintering, spawning, juvenile habitats, adult feeding habitat, etc. In the historic literature, spawning runs e.g. from sections of the Upper Danube far up into tributaries are reported (Ratschan, 2012). But there are some reasons to believe that even historically not all members of the population took part in such migrations. Nowadays, not many river systems are left where such habitats exist in high quality and are accessible barrier free. Therefore, huchen populations are restricted to river sections where the mentioned seasonal or ontogenetically different habitats are available on a smaller scale (Ratschan, 2012). Such rivers could be regarded as "typical" huchen rivers, but this statement is misleading regarding the huchen's niche in more pristine systems, where a network of habitats could support larger and spatially more structured populations. Furthermore, climate, hydrology and other abiotic factors like the specific riverbed structure of geologically different river types exist in different combinations in the distribution area. Therefore, a generalized description of huchen habitat on a scale from river drainages down to the microhabitat has to be done with caution.

In Austrian and Bavarian rivers, the upstream limit of huchen distribution was historically situated at the upstream end of the trout and grayling region according to Huet (1949), where river width is below $5-10 \mathrm{~m}$, mean discharge below $0.5-2 \mathrm{~m}^{3} \mathrm{~s}^{-1}$, the river slope exceeds 1 $\%$, and the altitude is $900 \mathrm{~m}$ above sea level (Ratschan, 2014). In alpine rivers, the upstream limit for the distribution of the Danube salmon is reached where the mean water temperature of the warmest month is as low as $10^{\circ} \mathrm{C}$ (Ratschan, 2012; 2014; Verweji, 2006). Tributaries or headwaters further upstream (to the upper trout region) might be nevertheless used as spawning habitats. Nowadays it is very common that the upstream limits lie downstream of the historical distribution area and are defined by man-made migration barriers.

"Typical huchen rivers", among them the ones where huchen populations are preserved in Austria and Bavaria, are currently situated in rivers between 3 and $150 \mathrm{~m}^{3}$ of mean discharge, a slope of $0.2-0.5 \%$, an altitude between 200 and $800 \mathrm{~m}$ and a mean temperature in the warmest month of $13-18^{\circ} \mathrm{C}$ (Ratschan, 2014). Such conditions often occur at the lower section of grayling zone (Decei 2001). 
On the downstream end of the distribution, limiting factors like high water temperatures, limited access to spawning grounds with clean gravel, or competition with predators that prefer warmer water, e.g. catfish (Silurus glanis L.) or zander (Sander lucioperca L.) occur and smaller rivers of the barbel or bream zone with more lowland than foothill characteristics (e.g. water temperature of the warmest month $>20^{\circ} \mathrm{C}$ or slopes of $<0.15 \%$ ) are hardly used by huchen. Some authors state that the maximum water temperature in huchen rivers is around $15^{\circ} \mathrm{C}$ (though they can sustain themselves up to $20^{\circ} \mathrm{C}$ if the flow is sufficiently high) with a dissolved oxygen of 8-9 $\mathrm{mg} \mathrm{L}^{-1}$ but not below $5 \mathrm{mg} \mathrm{L}^{-1}$

(Păsărin, 2007; Simonović et al., 2011). The mean of the warmest month (July or August) in huchen rivers in Austria lies between about 12 and $18^{\circ} \mathrm{C}$ (Ratschan, 2014). But some populations in smaller lowland rivers exist that are even warmer (warmest monthly mean of $20^{\circ}$ ), and where huchen tolerate temperatures up to 26$27^{\circ}$ as a short-time maximum of the diurnally fluctuating temperatures in summer. However, in river reaches with water abstraction at the river Pielach accumulations of adult huchen in pools with groundwater entry have been observed in hot summers, serving as potential key habitats for survival during these events (pers. communication M. Jungwirth).

Ratschan and Schmall (2011) and Ratschan (2012) show that even though very small rivers can hold surprisingly large huchen, the maximum size is well correlated to the size of the river. Adult huchen are territorial but not solitary, large specimens occupy and defend territories, usually a large pool, which may also be inhabited by several other individuals (Holč́k, 1995). Unfortunately anthropogenic impacts like channelization, damming, and deforestation have led to the degradation of the natural habitat of the huchen (Cristea, 2007; Geist et al. 2009), strongly limiting potential population sizes.

Quantitative information about habitat preferences of huchen on a smaller scale (meso-/ microhabitat) is very scarce. Data is available from a small (MQ $\approx 7 \mathrm{~m}^{3} \mathrm{~s}^{-1}$ ) foothill river, the Pielach in Austria (see Fig. 1; Holzer, 2000; 2011a). Microhabitat data were gathered by diving in nature-like sections during different seasons across two years. A relative broad range of habitats were used, but a narrow spectrum of preferred conditions became apparent: juveniles preferred shallower but slightly faster flowing habitats than sub-adult or adult individuals. Spawning habitats were characterized by a depth of about half a meter, velocities about $40-60 \mathrm{~cm} / \mathrm{s}$ and by micro $(20-63$ $\mathrm{mm})$ to mesolithal $(63-200 \mathrm{~mm})$ substrates. Data deficits remain concerning habitat choice and migration of several life-stages even in the relatively well-studied case of the river Pielach.

Care has to be taken, when transferring results from the river Pielach to rivers with different characteristics. For example, in rivers with less woody debris, $0+$ huchen are rather found in microhabitats shallower than $0.30 \mathrm{~m}$ (pers. observation C. Ratschan). They can be also found in isolated pools in the river floodplain with an influx of ground water, if such structures are available (pers. communication M. v. Siemens). There is only very limited knowledge about microhabitat choice, seasonal and ontogenetical habitat shifts and migration in large foothill and alpine rivers. This lack of data is a major reason for uncertainty concerning prognoses of anthropogenic impacts and rehabilitation measures on huchen habitats, which leads to discussions and misunderstandings

Reproduction. Huchen become sexually mature at an age of about 5 years and lengths of $65-70 \mathrm{~cm}$, but the age of maturity is strongly dependent on fish weight and can be also be reached earlier at weights of $\mathrm{l}-2 \mathrm{~kg}$ for males and 2-3 kg for females (Holčík, 1995). With the approach of spawning time, the parent fish reduce their natural timidity and the males undergo marked colour changes, turning red or copperred, which is why they are called "Rotfish" or "Rothuchen" in Austria and Germany, with males being slightly darker in comparison to the females (Prawochensky and Kolder, 1968). It is difficult to distinguish sexes out of the spawning season, since no obvious characteristics exist that would allow for a clear distinction.

Huchen is a spring spawning fish, belonging to the ecological group of rock and gravel hiders (Balon, 1990). In foothill rivers, spawning season can already start in late March, but in cold alpine rivers the spawning can take place until mid-May (Ratschan, 2014). Spawning time also depends on the stability of the water temperature and usually takes place once a year (Prawochensky and Kolder, 1968). 


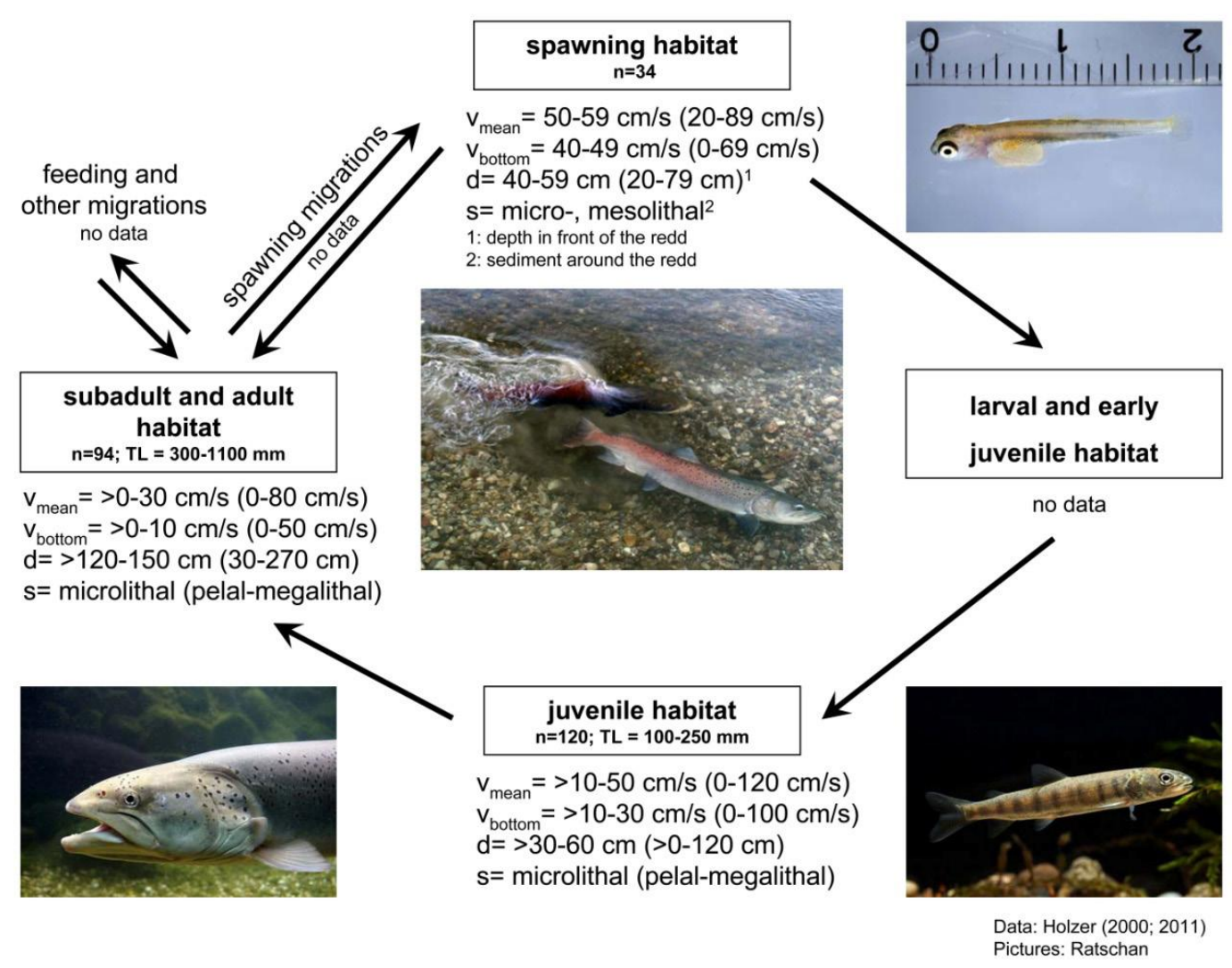

Fig. 1. Habitat use of different life stages of huchen in the River Pielach. Figures: preferred range (spawning habitat: preference index $>0.80$; juvenile/adult habitat: utilisation index $>0.80$ ). Figures in parenthesis: used range; $n$ : number of fish; TL: total length; v: water velocity; d: water depth; s: sediment type. For details see Holzer (2000;

2011a).

Holzer (2011a) monitored the spawning season of huchen in 1997 and 2000 on the river Pielach, where spawning occurred temperatures between $6.2^{\circ} \mathrm{C}$ and $9.5^{\circ} \mathrm{C}$ in 1997 and $6.1^{\circ} \mathrm{C}$ and $8.0^{\circ} \mathrm{C}$ in 2000 . For spawning, huchen can migrate in order to search for suitable spawning habitat (0.3-1.5 m deep) in the main river (Holčík, 1995). These migrations can cover distances between several and probably 100 kilometres and more, but spawning migrations can be restricted to just a few hundred meters, if huchen live in small rivers year-round, or find good spawning habitats near their year-round home range, or if they are not able to migrate due to barriers. There are hints that spawning in the main rivers can be preferred in years when factors like discharge, turbidity or temperature are not favourable in tributaries (Heckel, 1851; Anonymus, 1884; Neresheimer, 1938; Zitek et al. 2007; Ratschan, 2012). Generally, there is a strong lack of knowledge about the characteristics and intensity of spawning migrations. During the spawning event, as pairwise spawners, the male and female fish are positioned slightly one behind the other, and the male performs an intermittent quivering motion, which is a courtship behaviour consisting of low amplitude and high frequency body vibrations from head to tail (Esteve et al., 2013) while the female performs the nest digging by turning on her side and excavating a depression in the gravel by beating her tail. Esteve et al. (2013) divided the female digging in three types according to the progress of nest building as follows: nest starting digs (female progresses upstream while digging approximately 1-2m); nest finishing digs: female concentrates digging in one location with a medium tail beat intensity and the last egg covering digs: female progresses while digging (approximately 0.5-1 m), low intensity tail beating.

Holzer (2011a) observed 34 different huchen redds and found three different redd shapes: single redd with the redd tail downstream (25 
cases); single redd with the redd tail lateral to the flow direction (4 cases) and double redd with one tail ( 5 cases). On each redd the parameters water depth, mean water velocity, bottom water velocity, substratum, shadow, visual cover and structure were measured or described. Data on habitat availability for the whole river was also collected ( $\mathrm{n}=582)$. With this data utilizationand preference curves were calculated in order to characterize huchen redds (Tab.1) (Holzer, 2011a). Holzer (2011a) also described that female huchen might build more than one redd. In three cases females were observed digging two redds. These were single redds separated by a distance of
0.2 to $2 \mathrm{~m}$. The female started digging and after a while it moved upstream to dig a new redd where the spawning act happened. In five other cases the female huchen dug a double redd. In these cases huchen started digging a redd and after a while moved to the right or left and started digging a new redd. This showed that huchen also may dig "false redds" like other salmonids (Barlaup et al. 1994; Briggs, 1953; Edo et al. 2000; Hardy 1963).

Danube huchen spawning behaviour was generally observed to be similar to that of other salmonids and remarkably similar to that of Siberian taimen (Esteve et al., 2009a; Groot, 1996; Schroder, 1981). One female spawns with one

Tab. 1. Parameters that describe a huchen redd (from 34 different redds) (Holzer, 2011a)

\begin{tabular}{|c|c|c|}
\hline \multirow[t]{2}{*}{ Redd-Parameter } & \multicolumn{2}{|c|}{$\begin{array}{c}\text { Utilisation index } \\
\text { in (...) smoothed utilisation index }\end{array}$} \\
\hline & from-to & utilization index $>0,80$ \\
\hline water depth in front of the redd & $20-79 \mathrm{~cm}$ & $40-59 \mathrm{~cm}(40-59 \mathrm{~cm})$ \\
\hline mean water velocity in front of the redd & $20-89 \mathrm{~cm} / \mathrm{s}$ & $\begin{array}{c}50-59 \mathrm{~cm} / \mathrm{s}(40-59 \\
\mathrm{cm} / \mathrm{s})\end{array}$ \\
\hline bottom water velocity in front of the redd & $0-69 \mathrm{~cm} / \mathrm{s}$ & $\begin{array}{l}10-19 \mathrm{~cm} / \mathrm{s} \& 40-49 \\
\mathrm{~cm} / \mathrm{s}(10-49 \mathrm{~cm} / \mathrm{s})\end{array}$ \\
\hline sediment around the redd & micro-, meso- macrolithal & microlithal \\
\hline shadow on the redd & „no shadow“ till „full shadow“ & no shadow \\
\hline visual cover & $\begin{array}{c}\text { „no visual cover“ and „little } \\
\text { visual cover“ }\end{array}$ & no visual cover \\
\hline structure around the redd & $\begin{array}{l}\text { "no special structure“ and } \\
\text { „overhanging vegetation" }\end{array}$ & no special structure \\
\hline \multirow[t]{2}{*}{ Redd-Parameter } & \multicolumn{2}{|c|}{$\begin{array}{l}\text { Preference index } \\
\text { in (...) preference index calculated with the smoothed } \\
\text { utilization curve }\end{array}$} \\
\hline & from-to & preference index $>0,80$ \\
\hline water depth in front of the redd & $20-79 \mathrm{~cm}$ & $40-59 \mathrm{~cm}(60-69 \mathrm{~cm})$ \\
\hline mean water velocity in front of the redd & $20-89 \mathrm{~cm} / \mathrm{s}$ & $50-59 \mathrm{~cm} / \mathrm{s}(60-69 \mathrm{~cm} / \mathrm{s})$ \\
\hline bottom water velocity in front of the redd & $0-69 \mathrm{~cm} / \mathrm{s}$ & $40-49 \mathrm{~cm} / \mathrm{s}(40-49 \mathrm{~cm} / \mathrm{s})$ \\
\hline sediment around the redd & micro-, mesolithal & micro-, mesolithal \\
\hline shadow on the redd & $\begin{array}{l}\text { "no shadow" till „full } \\
\text { shadow" }\end{array}$ & no shadow \\
\hline visual cover & $\begin{array}{l}\text { „no visual cover" and „little } \\
\text { visual cover" }\end{array}$ & no visual cover \\
\hline structure around the redd & $\begin{array}{c}\text { no special structure \& } \\
\text { overhanging vegetation }\end{array}$ & no special structure \\
\hline
\end{tabular}

Note: For "shadow" parameter, there were four classes used (no shadow $<10 \%$, little shadow 10-50\%, middle shadow 50-90\% and full shadow>90\%); Parameter „visual cover" depends on water depths and structure (overhanging vegetation, submerged vegetation), also with four classes: no visual cover, little visual cover, middle visual cover and full visual cover. Parameter "structure around the redd": rockfill, big stones, submerged vegetation, overhanging vegetation, no special structure, broken water surface and washed shoreline. 
male, but Esteve et al., (2013) observed in the Ybbs river that a second male was trying to approach the nesting female, but the mating male repelled him powerfully by chasing him more than 30 meters away from the nest. Only once two males were recorded during this study without fighting. If a single pair spawning is the norm for huchen, sperm competition is not as great as it is for other salmonids like Salmo, Salvelinus and Oncorhynchus, among which multi-male spawnings are common (Esteve, 2005).

The eggs of $H$. hucho are 4.5 to $6 \mathrm{~mm}$ in diameter (Ivaska, 1951) and are of a yellow-orange colour. The number of eggs deposited depends on body weight with females producing between 1,200 and 1,500 eggs per kg body weight annually (Jungwirth, 1978). The period from fertilization to hatching is dependent on water temperature and lasts until there is an accumulation 250-300 degree days (Decei, 2001). The appearance of eyes in huchen larvae was noted by Nikcevic et al., (1998) on the $16^{\text {th }}$ day after fertilization. Hatching began on the $24^{\text {th }}$, one day after transferring the eggs to incubation trays at a time when $2 / 3$ of their yolk sack was consumed. The eggs also have numerous predators among fishes, the most common are: grayling (Thymallus thymallus L.), barbel (Barbus barbus), nase (Chondrostoma nasus L.) and many others, which eat eggs (mainly those not covered by gravel) during the spawning season. Another threat is the common parasite the fungus Saprolegnia which damages the egg membranes (Prawochensky and Kolder, 1968).

Genetics. The genus Hucho is represented by four species: $H$. bleekeri, $H$. hucho, $H$. taimen, $H$. ishikawae, which are distributed in Europe and Asia (Fishbase 2013). No genetic data exist for $H$. ishikawae and thus the phylogenetic placement of this taxon remains unconfirmed. The remaining three species have been studied cytogenetically by Arai (2011). Salmonid fishes are considered to be of autotetraploid origin (Allendorf and Thorgaard, 1984; Hartley, 1987; Ohno, 1970) and the tetraploid ancestor possessed a karyotype with 96 one-armed chromosomes (Nf=96) (Ohno, 1970; Phillips and Rab, 2001). The huchen karyotype consists of 82 chromosomes: 13 pairs of metacentric chromosomes, 2 pairs of submetacentric chromosomes and 26 pairs of subtelo-acrocentric chromosomes $(\mathrm{NF}=112)$, also the presence of 4 pairs of small-sized metacentric chromosomes called hucho markers were observed at chromosome pairs nos. 10, 11, 12 and 13, (Kucinski et al., 2014), with no differences between karyotypes of males and females. Kucinski et al. (2014) provide data on the combination of cytogenetic procedures including $\mathrm{C}$ banding, AgNO3 and CMA3 staining and chromosomal digestion with restriction endonucleases that provides original data on heterochromatin structure and distribution in the European huchen chromosomes, enabling better karyotype definition of this fish species.

Extensive DNA sequence data places Hucho, together with its sister genus Brachymystax as the basal clade of the sub-family Salmoninae (Crespi and Fulton, 2004; Crête-Lafreniere et al., 2012; Shedko et al., 2013), which includes the genera Salmo, Parahucho, Oncorhynchus (and Parasalmo), and Salvelinus. These studies, as well as earlier more limited investigations unanimously demonstrate that Sakhalin taimen Parahucho perryi are not a member of the genus Hucho, and are more closely related to Salmo and Oncorhynchus. Recent analysis of Hucho in the Urals demonstrated that these fish are indeed Siberian taimen $H$. taimen, with no intermediate relationship to huchen (Marić et al., 2014a).

Phylogeographic analysis of huchen across its range showed limited genetic variation at the species level compared to many other salmonids, but a statistically significant difference between populations of the upper Danube (Austria and Slovenia) compared to the rest of the range sampled, including Bosnia-Herzegovina, Montenegro, Slovakia and Ukraine (Weiss et al., 2011). These data along with a do-no-harm principle led to the recommendation that transport and stocking of brood fish or yearlings should not be carried out across the whole range of the species and the sale of huchen across international boundaries should be restricted if the natural genetic structure and potential local adaptations are to be preserved (Weiss et al., 2011). Population genetic level studies on huchen, applying microsatellite data are thus far limited to those of Geist et al. (2009) in Bavaria and local study in the Mur River, Graz Austria (Weiss and Schenekar (2012) and in the Drina River, Serbia (Marić et al., 2014b). Geist et al., (2009) suggested that an approach of genetic cluster-based conservation of European H. hucho 
may be useful where extensive migration and stocking has occurred. Weiss and Schenekar (2012), working in the framework of an environmental impact statement for a planned hydropower plant, demonstrated that despite historical stocking and an anthropogenically impacted environment population genetic data could be useful in evaluating the presence of a self-sustaining population versus dependency on stocking. Marić et al., (2014b) also showed that despite limited variation at the mtDNA molecular (a characteristic for the species) nuclear DNA markers can be used for identifying regionally specific stocks and the occurrence of individuals from distant sources. Thus there is a high potential for using microsatellite data for applied questions concerning the management of huchen at the local level.

In-situ conservation. Dams and regulation of rivers constitute a major threat for global freshwater species diversity including huchen. To improve habitat conditions, it is necessary to eliminate local sources of pollution, to build fish passes at dams and restructure channelized river stretches (Vörösmarty et al. 2010). Huchen can take advantage from efforts to restore migrations, e.g. building fishways or removing barriers, if such measures link favourable habitats, especially spawning grounds (Zitek et al. 2004; 2008). A further prerequisite for a successful re-establishment of river connectivity is that downstream migrations must also be supported without increased mortality, especially for postspawning adult huchen and their offspring. Summarizing, such measures must be able to minimize the barrier effect of a given obstacle in both directions.

Experience with the design of fish passes that are able to effectively support migration of adult or even very large huchen is still limited. This is primarily due to the fact that relatively few fish passes that meet modern criteria have been built in rivers with good huchen stocks. A collection of all available results of monitoring efforts from fish passes in huchen rivers showed, that in only 4 of 23 fish passes, a successful upstream passage of one or more adult huchen $(>65 \mathrm{~cm})$ could be observed (Ratschan, 2014). Several common types of fish passes were among these. Reviewing the technical characteristics, it seemed that fish passes that use all or most of the discharge of the river at low flows or a large proportion at mean or higher flows at obstacles not used for hydropower production were more successful than fish pass at hydroelectric plants, where only a small part of the total discharge is provided to the fish pass. At the latter, only one fishway with $0.4-0.5 \mathrm{~m}^{3}$ $\mathrm{s}^{-1}$ in a smaller river and one fish pass with 0.8 $\mathrm{m}^{3} \mathrm{~s}^{-1}$ of discharge in a larger river turned out to be successful to promote upstream passage of adult huchen. This phenomenon is most probably related to a lack of attraction of the adult huchen during their upstream passage to the entrance of a fish pass due to the competing flow from turbines, or a general wrong positioning of the fish pass entrance. Besides the appropriate positioning of the entrance and sufficient attraction flow other important characteristics of fish passes that provide successful upstream passage for fish comprise the gradient and the spatial dimensions (pool length and width, slot width) that, in relation to the total discharge needed for a specific fish pass construction at a given site, define important hydraulic parameters like water depth, flow velocity and turbulence (BMLFUW, 2012).

In Austria and Germany, guidelines have been developed where the requirements to construct efficient fish passes for different river types and fish species, including huchen, are given (BMLFUW, 2012; Seifert, 2012). As far as the huchen is concerned, the recommendations are still built on a relatively weak data basis. Furthermore, the aim of the cited guidelines is the use for rehabilitation measures to implement the Water Framework Directive of the European Union. This includes for example, that only adult huchen of lengths up to 0.8 $1 \mathrm{~m}$ (and thus only a limited part of the population) are regarded as decisive for the dimensioning of fish passes. Under certain circumstances, e.g. assessing the impact of new hydroelectric power plants or to reach the goals of the Habitats directive of the European Union, higher standards might be more appropriate, especially as long as no better data basis is available. Furthermore, the question of downstream migration urgently needs to be addressed scientifically. In many cases, not only re-establishing connectivity at dams and weirs, but also the restoration of habitats in good quality is an essential prerequisite for a successful conservation and rehabilitation of huchen populations (Zitek et al. 2008). Only few published studies evaluate examples and 
provide recommendations for successful habitat restoration measures for huchen (Ratschan, 2014; Schmutz et al. 2002).

Since huchen is listed in the annex II of the European habitats directive, a number of projects (so called "LIFE projects") have been realized with the goal to restore huchen habitat (among other species), and obligatory monitoring of ecological short term-effects. Ratschan (2014) provides a short review of the success of those measures to support huchen populations. Many of the realized measures, such as re-activated side-branches, widening of the river bed, reconstruction of gravel bars and so on, showed good or even very good success that could be measured by an increase of fish abundance and diversity only a few years after construction. But unfortunately, hardly any increase of huchen abundance, especially early life stages, could be documented. Reasons for this may include:

- The monitoring was conducted only a few years after the construction, probably too early to be able to document effects over several fish generations or after recovery of prey species;

- Overlying factors, that can strongly affect huchen populations, could not be eliminated or even increased. These can include rising of water temperatures, influence of other predators (e.g. birds or other predatory fish) or alien species, hydropeaking, lack of gravel or increased input of fine sediments, and construction of new hydroelectric power plants;

- The measures were on a small-scale and did not systematically change availability of habitats (Schmutz et al., 2014);

- The restoration measures were not properly planned or realized. Considering this experience, the following recommendations can be derived:

- Before the planning of measures, the key deficits and the most effective measures to eliminate these deficits have to be identified and prioritized accordingly;

- Habitat rehabilitation should always be oriented on the pristine condition of a given river and must take the river-type-specific characteristics into account (Muhar et al., 1995). In this case, a good long-term function for many species including huchen can be expected;

- Technical or small-scale solutions, such as building groynes, technical fish passes, side-branches with little morphological dynamics or without providing shallow areas should only be built if alternatives are not possible;

- Nature-like hydraulic habitats and a naturelike hydrological regime (no impoundment or hydropeaking), is a prerequisite for successful habitat reconstruction for rheophilic fish such as huchen;

- The restoration of high quality spawning grounds has to be addressed with special focus. Measures such as the active input of bed sediments or the facilitation of dynamic processes must be taken into account in case of a deficit of non-silted gravel spawning places (Hauer et al., 2013);

- In many cases, the creation of shallow shore areas is essential to reconstruct habitats for juvenile huchen and their prey. The long-term availability of such habitats can only be provided if the existing morphological and hydraulic dynamics hinder a unidirectional accumulation of sediments.

For long-term in-situ conservation, large and connected populations will be necessary, taking into account the meta-population structure (Schmutz et al., 2004). Effective upstream and downstream migration facilities and a dense network of high quality habitats are especially important for a large, long-living predatory fish such as huchen.

Ex-situ conservation. The first information regarding huchen culture dates from 1876 (Stráňai, 2012). Due to the significant decrease of the Danube salmon populations, the need for hatchery incubation and stocking was recognized. Further attempts of hatchery production of huchen were made in Austria, former Czechoslovakia and Yugoslavia by placing just emerged alevins into ponds with a high natural food supply, with several hatcheries succeeding in rearing fingerlings (Jungwirth, 1978). Significant culture success was achieved only with the implementation of artificial reproduction procedures and juvenile rearing techniques based on replacing natural feeds (Grudniewska et al., 2013) with commercial starters (Kowalewska-Hryc et al., 2005). Active protection measures for Danube huchen in most countries are limited to stocking programs or placing the fish under protection during spawning. In many countries, as in Romania, there is only one hatchery delivering Danube huchen and the interest in reproducing this species is declining; in 
Poland the number of hatchery facilities producing huchen has shrunk from nine to just one (Witkowski et al., 2013a). A continuous genetic monitoring of hatchery stocks and of additional samples from the wild could increase our sustainable conservation management of the species. Fisheries management strategies will be most effective if they simultaneously combine knowledge of the genetic structuring of $H$. hucho populations and of the species' biology. Unfortunately, its current status in Europe is critical and it has disappeared from most of its original range, and only a few selfsustaining populations have survived (Esteve et al., 2013). Today, many of the remaining populations are thought to be influenced by stocking (Holčík, 1995), with potential negative consequences on genetic variability and other problems associated with hatchery fish propagation (Alvarez and Nicieza, 2003; Araki et al., 2007; Fleming and Petersson, 2001; Fraser, 2008). Geist et al. (2009) noted that even if wild fish are used as spawners, still strong negative effects on the gene by the common practice of mixed-milt fertilization can be expected, due to sperm competition, a very powerful kind of sexual selection (Birkhead and Møller, 1998; Snook, 2005; Wedekind et al., 2007). Similarly, the conditions used for artificial reproduction and rearing may coincide in many respects with selection of genotypes that have low viability in the wild. Thus there is a strong need to develop protocols for artificial reproduction and re-stocking to optimize the success of any restocking and to avoid the negative consequences of stocking fish in natural populations. New methods like artificial in-river propagation ('Cocooning', Holzer, 2011b) could be tested and applied for Danube salmon on a larger scale. From the genetic perspective, following the rule-ofthumb "50/500" rule (Soulé and Wilcox, 1980) at least 50 adult huchen should be used for founding a brood stock for supplementation programs to insure that less than $1 \%$ of the genetic variability would be lost each generation. However, Allendorf and Ryman (1986) argue that this number is an order-of-magnitude too small due to the high variance in family size prevalent among salmonids. Considering logistic constraints it would thus appear impossible to use a fixed brood stock for a supplementation program in huchen without assuming loss of genetic variation.
Holzer (2011b) noted that Richard Vibert (Vibert, 1953) was one of the first people in the 50 s of the last century who provided incubators for salmonids. He developed small, unilocular breeding boxes for up to 200 eggs. These boxes were filled with fertilized eggs and buried in the substrate of the watercourse. The larvae hatch in the box, leave it and remain in the interstitial (void space of the ballast bed) until the yolk sac is resorbed to emerge afterwards. After leaving the interstitial, larvae are seeking shallow and slowflow areas along the shorelines. Whitlock (1978) developed the Vibert-box further and added a second chamber. The fertilized eggs were placed in the upper chamber. Due to their photophobia, the larvae are collected in the lower chamber. Once the yolk sac is resorbed, the fish larvae emerge to the surface. The Vibert- and Whitlock-Vibert-boxes are open incubators, i.e. the fish larvae may leave the box itself after the development openings. The two main disadvantages of these types of boxes are the low egg capacity and the apparition of the fungal contamination of the introduced eggs. The eggs are introduced without substrate and therefore a possible fungus infection can affect all eggs. In addition to the brood boxes above there are several other types of boxes and incubators "Firzlaff-Box" (Firzlaff, 1996), Bollinger Box, $\mathrm{m}+\mathrm{s}$ Brutbox system and various homemade boxes.

Cocooning according to Holzer (2011b) pursues a sustainable ecologically based management with the goal of ultimately "sustaining populations to establish themselves" in a body in water. The introduction of fertilized eggs in hatching boxes in the main river and in suitable tributaries should hereby mimic natural reproduction. By building the cocoons, the natural conditions that are required for a volume of fry, are simulated. In a brood chamber filled with gravel and stone fractions, fertilized fish eggs are introduced and after the sealed cocoon is buried in the river bed, eggs can develop under quasi-natural conditions. The newly hatched, good moving, but barely floatable fish larvae migrate through the void space of the substrate and finally get through the perforated partition in the larval chamber, where they consume their yolk sac. The supply of eggs and the larvae with the dissolved oxygen in the water is ensured by the permeable properties of the protective covering of the cocoon. Furthermore, a metal lattice covering the housing fulfils a protec- 
tive function against natural spawning predators and prevents premature escape of buoyant larvae from the cocoon. A review of the hatching rate as an important success control for the managers is made possible. Due to the principle of "homing" (the return for reproduction to place of birth) of fish naturally hatched from such an artificial inriver spawning place, new potential spawning areas may be initiated with this method. This aspect seems particularly worth considering in highly fragmented river systems, since historical spawning grounds are often no longer accessible due to continuum interruptions so that new spawning grounds have to be initiated and also subsequently maintained. Another important aspect, why cocooning might be favoured in relation to conventional aquaculture programs is the appearance of domestication of fish in hatcheries. The longer the fish are hosted in aquaculture, the bigger the domestication effect can get. With cocooning (eyed eggs) the domestication effect can be expected to be zero. Holzer during the last 15 years has successfully used this method for brown trout, grayling, rainbow trout, lake trout, Atlantic salmon and marbled trout, but also recently for huchen. In all cases very good breeding successes between $80-95 \%$ were reached.

Araki et al. 2007 showed that even when the progeny of wild fish is used for stocking the reproduction rate of returning steelheads (Oncorhynchus mykiss) stocked as smolts decreases to $40 \%$ each generation. In the mean time Milot et al. (2013) confirmed this result with Atlantic salmon. In this study the authors showed that relative reproductive success varied with life stage at the time of stocking, being 0.71 for fish released at the fry stage and 0.42 for fish released as smolts. Theriault et al. (2010) also explored how the performance of returning adults released as unfed fry differ from those released as smolts. They showed that the return rate of unfed fry was lower than that of smolts, but the returning adults from fry release performed more like the wild fish. For example, fish released as smolts were significantly smaller upon returning as adults than either those released as unfed fry or wild returns. The incidence of jacking (males returning at age 2) was also greater among fish stocked as smolts than for fish stocked as fry. Differences in survival, relative reproductive success and life history appeared to be the result of hatchery practices and indicated that a fry stocking strategy produced fish more similar to the wild component of the population than to that of fish released as smolts.

Till today there is no research how stocking with fertilized eggs differs from smolt release, but there is a good chance that this practice will produce fish very similar to the wild fish. However, also when using fertilized eggs there are still some other problems, for example mate choice. But very little is known about the potential effects in such case and further research is required. But with the existing knowledge using fertilized eggs for stocking can be seen as the most favorable method. Also the homing effect, which exists in all salmonids, could be initiated with this method. It is still not known when exactly the imprinting of homing occurs, but when using fertilized eggs for stocking, this can be most probably achieved. However, still artificial rearing programs in hatcheries combined with detailed research on physiology, fertility, behavior, performance etc. and a comprehensive genetic program, also in comparison to fish stemming from natural reproduction in rivers, can be of high value for the conservation of a species as shown in the case of sturgeon (Chebanov and Galich, 2013).

\section{Conclusion and outlook}

The rehabilitation of functionally adapted, self-sustaining $H$. hucho populations does not only have symbolic character, but is also likely to have positive effects on other species inhabiting the same ecosystem and on overall stream ecosystem health in the Danube system. In Europe, we as scientists are responsible for providing advice to governments, local environmental agencies, and angling associations, as well as raising awareness among the local communities by presenting the environment related legislation on the protection of rare species such as huchen and we emphasize that habitat rehabilitation and preservation are the best and in the long run more or less the only effective techniques to conserve huchen in our rivers (Esteve et al., 2013). A new bridge for collaboration between foresters, hydrobiologists and angling associations could optimize the management of aquatic ecosystem health. 


\section{Summarized, further activities should focus on:}

- Update and define distribution areas of Danube salmon, also in IUCN databases (e.g. some rivers of occurrence in Romania not listed)

- Coordinated development of conservation programs with the frame of existing legislation (FFH, NATURA 2000)

- Increase knowledge concerning successful habitat rehabilitation measures, including upstream and downstream migration facilities, hydropeaking, sediment management and structural rehabilitation of rivers.

- Development of guidelines for effective habitat rehabilitation measures for the Danube salmon.

- Rehabilitation of habitats and re-establishment of connectivity at artificial barriers and weirs for whole fish communities, as huchen also strongly depends on the availability of prey fish.

- Development of best practices for artificial reproduction and stocking of Danube salmon.

- Monitoring to document trends in population structure and size, together with genetic monitoring.

- Collection and storage of available data in a GISbased database.

- Inclusion of important stakeholder groups in the management of Danube salmon populations (e.g. fishermen, local population, politicians).

Acknowledgments. This paper was published under the frame of European Social Fund, Human Resources Development Operational Programme 2007-2013, project no. POSDRU/159/1.5/S/132765. Also as the first author of this paper I would like to express my gratitude and appreciation to all those who contributed to this publication with suggestions and encouragement and the provision of information. A special thanks goes to A. Zitek for successfully building the author team. Due to this approach, it was possible to base the review on a collaborative collection and review of existing literature with the participation of renowned experts with regard of Danube salmon biology, genetics and conservation.

\section{REFERENCES}

1. Álvarez D, Nicieza AG (2003). Predator avoidance behavior in wild and hatchery - reared brown trout: the role of experience and domestication J. Fish Biol 63:1565-1577.
2. Allendorf FW, Thorgaard GH (1984). Tetraploidy and the evolution of salmonid fishes. In: Turner BJ (ed.) Evolutionary Genetics of Fishes. Plenum Press, New York, pp. 1-54.

3. Allendorf FW, Ryman N (1986). Genetic management of hatchery stocks, Pages 141-159 in Ryman N and Utter F (editors), Population Genetics and Fisheries Management. University of Washington Press, Seattle and London, 414 pages.

4. Andreji J, Stráňai I (2013). Growth parameters of huchen, Hucho hucho (L.), in the wild and under culture conditions. Arch. Pol. Fish. 21:179-188.

5. Anonymus (1884). Rechenschaftsbericht des Oberösterreichischen Fischerei-Vereines über das Jahr 1883. Mitt. österr. Fisch.-Verein 4:87-91.

6. Arai R (2011). Fish Karyotypes. A Check List. Springer Tokyo Berlin Heidelberg NY. 340.

7. Araki HB, Cooper MS, Blouin (2007). Genetic effects of captive breeding cause a rapid, cumulative fitness decline in the Wild. Science Vol. 318, pp.100-103.

8. Augustyn L, Witkowski A, Błachuta J (1998). Ecology of the young $(0+)$ Huchen, Hucho hucho (L.) (Salmonidae), planted in a mountain streams. Arch. Pol. Fish. 6:5-18.

9. Balon EK (1990). Epigenesis of an epigeneticist: the development of some alternative concepts on the early ontogeny and evolution of fishes. Guelph Ichthyol. Rev. 1:1-42.

10. Barlaup BT, H Lura H, Saegrov \& RC, Sundt (1994). Interand intraspecific variability in female salmonid spawning behaviour. Can. J. Zool. 72:636-642.

11. Bastl I, Holčík J (1968). On the fecundity and food of the Danubian salmon in the Orava Reservoir. Polov a rybar 20:18 (in Slovak).

12. Bastl I, Kirka A (1958). Study on morphological characters of huchen growth under natural and artificial conditions during the first year of life. Záverećná správa, SAV, Laboratorium rybárstva, Bratislava, 197 p. (in Slovak).

13. Bănăduc D, Răchită R, Bănăduc CA, Gheorghe L (2008). The Hucho hucho (Linnaeus, 1758), (Salmoniformes, Salmonidae), species monitoring in the Vişeu River (Maramureș, Romania). Transilv. Rev. Syst. Ecol. Res. 5:183-188.

14. Bănărescu P (1964). Fauna Republici populare Române. Bucureşti, Ed. Acad. Rep. Pop. Rom., vol.13: 960.

15. Berg LS, Arbor A, Michigan, Edwards JW (1947). Clasification of fishes both recent and fosil. 517.

16. Bertok M (2010). Plan for implementation of the fisheries management in the Sava River in the period 2011-2016. Zavod Za Ribištvo Slovenije Spodnje Gameljne 61 A, 1211 Ljubljana-Šmartno, 85.

17. Birkhead TR, Møller AP (1998). Sperm Competition and Sexual Selection. London, Academic Press.

18. BMLFUW (Hrsg., 2012). Leitfaden zum Bau von Fischaufstiegshilfen. Wien, Dezember 2012.102 S.

19. Bud I, Vlădău V, Nădaşanu M (2010). Tratat pentru creșterea peștilor. Ed. Texte, Cluj-Napoca. 
20. Briggs JC (1953). The behavior and reproduction of Salmonid fishes in a small coastal stream. State of California Department of fish and game marine fisheries branch. Fish Bulletin no 94.

21. Chebanov MS, \& Galich EV, (2013). Sturgeon hatchery manual, Ankara: FAO, Fisheries and Aquaculture Technical Paper http://www.fao.org/docrep/017/i2144e/i2144e. pdf (accessed at 06.10.2014). 558. 303.

22. Crespi BJ, Fulton M (2004). Molecular systematics of Salmonidae: combined nuclear data yields a robust phylogeny. Mol. Phylo. Evol. 31:658-679.

23. Crăte-Lafreniere A, Weir LK, Bernatchez L (2012). Framing the Salmonidae Family Phylogenetic Portrait: a more complete picture from increased taxon sampling. Plus One 7(10), e46662.

24. Cristea I (2007). Managementul fondurilor piscicole din apele de munte. Ed. Silvică pg. 113-122 București. (in Romanian)

25. Decei P (2001). Creşterea salmonidelor. Ed. a-II-a. Ed. Terra Design Gura Humorului.

26. Edo K, Kawamula H, Higashi S (2000). The structure and dimensions of redds and egg pockets of the endangered salmonid, Sakhalin taimen. J. Fish Biol. 56:890-904.

27. Esteve M (2005). Observations of spawning behavior in Salmoninae: Salmo, Oncorhynchus and Salvelinus. Springer Reviews in Fish Biology and Fisheries 15:1-21.

28. Esteve M, Gilroy D, McLennan DA (2009a). Spawning behaviour of taimen (Hucho taimen) from the Uur River, Northern Mongolia. Environ. Biol. Fish. 84:185-189.

29. Esteve M, Unfer G, Pinter K, Doadrio I (2013). Spawning behavior of Danube huchen from three Austrian river. Arch. Pol. Fish. 21:169-177.

30. Freyhof J, Kottelat M (2008). Hucho hucho In: IUCN 2013. IUCN Red List of Threatened Species. Version 2013.1. $<$ www.iucnredlist.org>. Downloaded on 12 September 2013.

31. Fishbase (2013). http://www.fishbase.org. Accessed 15 November 2013.

32. Firzlaff D. (1996): Edelstahlbox zur Erbrütung von Salmonideneiern in natürlichen Fließgewässern. Österr. Fisch. (49) 8/9 185.

33. Fleming IA, Petersson E (2001). The ability of released, hatchery salmonids to breed and contribute to the natural productivity of wild population. Nordic J. of Freshwater Research, 75:71-98.

34. Fraser DJ (2008). How well can captive breeding programs conserve biodiversity? A review of salmonids. Evol. Appl. 1: 535-586.

35. Geist J, Kolahsa M, Gum B, Kuehn R (2009). The importance of genetic cluster recognition for the conservation of migratory fish species: the example of the endangered European huchen Hucho hucho (L.). J. Fish Biol. 75:10631078.

36. Groot C (1996). Salmonid life histories. In: Principles of salmonid culture (Eds) W. Pennell, A. Bruce. Elsevier, New York, 97-230.
37. Grudniewska J, Przybył A, Goryczko K, Andrzejewski W (2013). Preliminary attempts to start feed huchen (Hucho hucho). Arch. Pol. Fish. 21:225-227.

38. Hanel L, Lusk S, Andreska J (2013). Huchen in the Czech Republic: A review. Arch. Pol. Fish. 21:143-154.

39. Hauer C, Unfer G, Habersack H, Pulg U, \& Schnell J (2013). Importance of River Morphology and Sediment Transport for the Quality and Sustainability of Spawning Gravel Beds. Wasserbau und Wasserwirtschaft 6 (4): 189-197.

40. Hardy JC (1963). An examination of eleven stranded redds of brown trout (Salmo trutta) excavated in the Selwyn River during July and August 1960. New Zealand Journal of Science, 6,107-119.

41. Hartley SE (1987). The chromosomes of salmonid fishes Biol. Rev. Cambridge 62:197-214.

42. Heckel J (1851). Berichteiner auf Kosten der kais. Akademie der Wissenschaften durch Oberösterreich und Salzburg, München, Innsbruck, Bozen, Verona, Padua, Venedig und Triest unternommenen Reise. Sitzungsberichte der mathematisch-naturwissenschaftlichen Classe der kaiserlichen Akademie der Wissenschaften. 7. Band, Heft 6-10:281-333.

43. Holčík J, Hensel K, Nieslanik J, Skacel L (1988). The Eurasian huchen, Hucho hucho, largest salmon of the world - Dr W. Junk Publisher, Dordrecht-Boston-Lancaster, 239.

44. Holčík J (1990). Conservation of the huchen, Hucho hucho (L.), (Salmonidae) with special reference to Slovakian rivers. J. Fish Biol. 37 (Suppl. A): 113-121.

45. Holčík J (1995). Threatened fishes of the world: Hucho hucho (Linnaeus 1758) (Salmonidae). Env. Biol. Fish. 43: 105-106.

46. Holzer G (2000). The habitat choice of the danube salmon (Hucho hucho) in the river Pielach. Habitateinnischung des Huchens (Hucho hucho) an der Pielach. Master thesis. Inst. of Hydrobiology \& Aquatic Ecosystem Management, University of Natural Resources and Life Sciences, Vienna, 111.

47. Holzer G (2011a). Habitat characterization of Danube salmon redds in the river Pielach/Habitatbeschreibung von Huchenlaichplätzen an der Pielach. Österr. Fisch. 64, 54-69.

48. Holzer G (2011b). Cocooning an alternative method for fisheries management/Cocooning eine alternative Methode zur fischereilichen Bewirtschaftung. Österr. Fisch. 64, 16-27.

49. Huet M (1949). Aperçu des relations entre la pente et les populations piscicoles des eaux courantes. Schweizerische Zeitschrift für Hydrologie 11: 332-351.

50. IUCN (2014). IUCN Red List Categories.

51. Ivaska S (1951). Hlavátka jej lov a umely chov. Bratislava, Tatran, $87 \mathrm{p}$.

52. Ivanc M (2012). The Danube Salmon - Hucho hucho (Linnaeus, 1758) in Slovenia: distribution, threats, conservation. Book of Abstracts II International Hucho Symposium (Eds) A. Witkowski, J. Kotusz, K. Goryczko, B.M. Pokryszko, J. Kusznierz, Mus. Nat. Hist., Univ. Wrocl., Wroclaw:30. 
53. Jungwirth $M$ (1978). Some notes to the farming and conservation of tile Danube salmon (Hucho hucho) Limnologisches Institut der Osterreichischen Akademie der Wissenschaften, Berggasse, Vienna. Env. Biol. Fish. Vol. 13, No. 2, 231-234.

54. Košeo J (2012). God save the Queen. Book of Abstracts II International Hucho Symposium (Eds) A. Witkowski, J. Kotusz, K. Goryczko, B.M. Pokryszko, J. Kusznierz, Mus. Nat. Hist., Univ. Wrocl., Wroclaw: 30-31.

55. Kottelat M, Freyhof J (2007). Handbook of European freshwater fishes. Kottelat, Cornol, Switzerland and Freyhof, Berlin, Germany, 646.

56. Kowalewska-Hryc I, Hryc M, Epler P (2005). Influence of different types of feed on growth and survival rates in huchen fry (Hucho hucho L.) - Komun. Ryb. 5:5-7.

57. Kucinski M, Ocalewicz K, Fopp-Bayat D, Liszewski T, Furgala-Selezniow G, Jankunm. (2014). Distribution and heterogeneity of heterochromatin in the European (Hucho hucho Linnaeus, 1758) (Salmonidae). Folia Biologica (Kraków) 62:81-89.

58. Krajč T, Štencl R, Hureala P (2012). The Danube salmon - Hucho hucho (Linnaeus, 1758) in Slovakia (protection, breeding and fishing). Book of Abstracts II International Hucho Symposium (Eds) A. Witkowski, J. Kotusz, K. Goryczko, B.M. Pokryszko, J. Kusznierz, Mus. Nat. Hist. Univ. Wrocl., Wroclaw: 32.

59. Marić S, Alekseyev S, Snoj A, Askeyev O, Askeyev I, Weiss S (2014a). First mtDNA sequencing of Volga and Ob basin taimen Hucho taimen: European popualtions stem from a late Pleistocene expansion of $\mathrm{H}$. taimen out of western Siberia and are not intermediate to Hucho hucho. Journal of Fish Biology 85:530-539.

60. Marić S, Razpet A, Nikolić V, Snoj A, Simonović P (2014b). Analaysis of genetic structure of huchen (Hucho hucho) in Serbia inferred from mitochondrial and nuclear DNA. Acta Veterinaria-Beograd 64(2), 236-244.

61. Matzinger A (2012). Zustand, Schutz und Bewirtschaftung der Donaufischbestände in Baden-Württemberg. Aktuelles aus Fluss- und Seenfischerei, AUF AUF 3:18-21.

62. Mateleshko OY, Potish LA (2011). Red Book of Ukrainian Carpathians. Wildlife - Uzhorod, Karpaty, 366.

63. Mikavica D, Savić N (1999). Ribe rijeke Drine (Fish of River Drina). Poljoprivredni Fakultet u Banjoj Luci, Banja Luka, 84.

64. Milot EC, Perrier L, Papillon JJ, Dodson \& L, Bernatchez (2013). Reduced fitness of Atlantic salmon released in the wild after one generation of captive breeding. Evolutionary Applications. Published by Blackwell Publishing Ltd 6 (2013) 472-485.

65. Mijović-Magdić J (2007). The current status of the huchen, Hucho hucho (Linnaeus, 1758), in Serbian waters and possibilities for its controlled spawning and rearing of juveniles. Doctoral dissertation, Faculty of Agriculture, University of Novi Sad, Novi Sad, Serbia, 175.

66. Mrakovčić M, Brigić A, Buj I, Ćaleta M, Mustafić P, Zanella D (2006). Red Book of freshwater fish of Croatia/Crvena knjiga slatkovodnih riba Hrvatske. Ministry of Culture, State Institute for Nature Protection, Zagreb, 253.
67. Muhamedagić S, Habibović E (2013). The state and perspective of Danube huchen (Hucho hucho) in Bosnia and Herzegovina. Arch. Pol. Fish. 21:155-160.

68. Muhar S, Schmutz S \& Jungwirth M (1995). River restoration - goals and perspectives. Hydrobiologia 303:183-194.

69. Neresheimer E (1938). Ostmärkische Salmonidenfragen. Int. Rev. d. Hydrobiol. 37:456-462.

70. Nikcevic M, Mickovic B, Hegediš A, Andjus RK (1998). Feeding habits of huchen Hucho hucho (Salmonidae) fry in the River Trešnjica, Yugoslovia. Ital. J. Zool., 65, Suppl.: 231-233.

71. Nowioki M (1889). O rybach dorzeczy Wisly, Styru, Dniestru i Prutu w Galicji. Cracow, 54

72. Ohno S (1970). Evolution by gene duplication. Springer Verlag, New York.

73. Pavlík L (1998). A note to huchen stocking. Rybárstva 3:89.

74. Păsărin B (2007). Salmonicultură practică. Ed. Alfa 69-71 Iaşi.

75. Phillips RB, Rab P (2001). Chromosome evolution in the Salmonidae (Pisces): an update. Biol Rev (Cambridge) 76:1-25

76. Prawochensky R, Kolder W (1968). Synopsis of biological data on Hucho hucho (Linnaeus, 1758). Food and Agriculture Organization on the United Nations Rome, 32.

77. Ratschan C, Schmall B (2011). Did the Danube salmon originally occur in the River Steyr? An example for difficulties with the reconstruction of the historic fish fauna. Österr. Fisch. 64, 188-197.

78. Ratschan C (2012). Maximum size and distribution limits of the Danube salmon (Hucho hucho) as a function of river size and geology in Austria and Bavaria. II International Hucho Symposium, 19-22 September 2012, Opuszna, Poland, Book of Abstracts. 40.

79. Ratschan C, Zauner G (2012). Past and present situation of huchen, or Danube salmon, in Upper Austria, future prospects. Österreichs Fischerei 65:250-258.

80. Ratschan C (2014). Aspekte zur Gefährdung und zum Schutz des Huchens in Österreich. Den 33.

81. Schedko SV, Miroshnichenko IL, Nemkova GA (2013). Phylogeny of Salmonids (Salmoniformes: Salmonidae) and its molecular dating: analysis of mtDNA. Russian Journal of Genetics (English version), 49(6), 623-637.

82. Schroder SL (1981). The role of sexual selection in determining overall mating patterns and mate choice in chum salmon. Ph.D. thesis, University of Washington, Seattle, WA, 274.

83. Schmutz S, Zitek A, Zobel S, Jungwirth M, Knopf N, Kraus E, Bauer T, Kaufmann T (2002). Integrated approach for the conservation and restoration of Danube salmon (Hucho hucho L.) populations in Austria. Freshwater Fish Conservation - Options for the Future (Eds) MJ CollaresPereira, IG Cowx and MM Coelho, Fishing News Books, Blackwell Science, Oxford:157-173.

84. Schmutz S, Wiesner C, Preis S, Muhar S, Unfer G \& M, Jungwirth (2011). Beurteilung der ökologischen Auswirkungen eines weiteren Wasserkraftausbaus 
auf die Fischfauna der Mur. Studie i. A. des Amts. Der Steiermärkischen Landesregierung, FA 19A:1-64.

85. Schmutz S, Kremser H, Melcher A, Jungwirth M, Muhar S, Waidbacher H \& Zauner G (2014). Ecological effects of rehabilitation measures at the Austrian Danube: a metaanalysis of fish assemblages. Hydrobiologia 729:49-60.

86. Schulz N (1985). Das Wachstum des Huchens (Hucho hucho L.) in der Drau in Kärnten - Österr. Fisch. 38:133142.

87. Seifert K, (2012). Praxishandbuch Fischaufstiegsanlagen in Bayern. Hinweise und Empfehlungen zu Planung, Bau und Betrieb. Herausgegeben durch den Landesfischereiverband Bayern e.V. 149 S.

88. Simonović P, Nikolić V, Tošić A, Marić S (2011). Lengthweight relationship in adult huchen Hucho hucho (L. 1758) from Drina River, Serbia, Biologia, Bratislava, 66:156-159.

89. Smolian K (1920). Merkbuch der Binnenfischerei. Würzburg, Berlin, Bd I, II, 128.

90. Snook RR (2005). Sperm in competition: not playing by the numbers. Trends in Ecology and Evolution 20:46-53.

91. Staff F (1950). Freshwater fish in Poland and neighboring countries - Wydawnictwo Trzaska, Evert and Michalski, Warszawa, 286.

92. Stráňai I (2012). Samuel Ivaška the pioneer in the Danube Salmon farming. Book of Abstracts II International Hucho Symposium (Eds) A. Witkowski, J. Kotusz, K. Goryczko, B.M. Pokryszko, J. Kusznierz, Mus. Nat. Hist., Univ. Wrocl. Wroclaw: 45-46.

93. Šubjak J (2013). Observations of food and feeding of angler-caught huchen, Hucho hucho (L.), in Slovak rivers in winter. Arch. Pol. Fish. 21: 219-225.

94. Soulé ME, Wilcox BA (1980). Conservation Biology: An Evolutionary Perspective. Sunderland Massachusetts, U.S.A. 395 pages.

95. Theriault V, GR, Moyer \& MA Banks (2010): Survival and life history characteristics among wild and hatchery coho salmon (Onchorhynchus kisutch) returns: how do unfed fry differ from smolt releases? Can. J. Fish. Aquat. Sci. 67:486-497.

96. Velykopolskyy I (2012) Huchen in Zakarpattya. Sztuka Łowienia 1(12):35-37.

97. Velykopolskiy I, Mruk A (2012). The Danube Salmon in the Zakarpatye Region of Ukraine: current state and perspectives - In: Book of Abstracts II International Hucho Symposium (Eds) A. Witkowski, J. Kotusz, K. Goryczko, B.M. Pokryszko, J. Kusznierz, Mus. Nat. Hist., Univ. Wrocl., Wroclaw: 52-53.

98. Verweij GH (2006). Analyse des historischen Vorkommens von Nase, Barbe und Huchen in Österreich als Grundlage für die Erstellung einer potentiellen Verbreitungskarte. Diplomarbeit, Univ. für Bodenkultur Wien, $106 \mathrm{~S}$.
99. Vibert R (1953). Plastic hatching box for stocking trout and salmon. The progressive Fish Culturist 13, 228.

100. Vörösmarty CJ, McIntyre PB, Gessner MO, et al., (2010). Global threats to human water security and river biodiversity. Nature 467:555-561.

101. Wedekind C, Rudolfsen G, Jacob A, Urbach D, and Müller $R$ (2007). The genetic consequences of hatcheryinduced sperm competition in a salmonid, Biological Conservation 137:180-188.

102. Weiss S, Maria S, Snoj A (2011). Regional structure despite limited mtDNA sequence diversity found in the endangered Huchen, Hucho hucho (Linnaeus, 1758). Hydrobiologia, 658:103-110.

103. Weiss S, Schenekar T (2012). Mur-Huchen Erweiterung des genetischen Nachweises von Fremdbesatz und natürliche Reproduktion. . Österr. Fisch. 65/2012, 136147.

104. Whitlock D (1978). The Whitlock-Vibert box handbook, Federation of Fly Fishermen Public.

105. Witkowski A, Błatucha J, Kowalewski M (1984). Growth rate of huchen introduced into the Dunajec River. Gosp. Ryb. 34: 15-16.

106. Witkowski A (2003). The Huchen Hucho hucho (L) -saved for the Polish ichthyofauna. Suppl. Acta Hydrobiol. 6:109-113.

107. Witkowski A, Goryczko K, Kowalewski M (2013a). The history of huchen, Hucho hucho (L.), in Poland, distribution, restoration, and conservation. Arch. Pol. Fish. 21:161-168.

108. Witkowski A, Bajić A, Treer T, Hegediš A, Marić S, Šprem N, Piria M, Kapusta A (2013). Past and present of and perspectives for the Danube huchen, Hucho hucho (L.), in the Danube basin. Arch. Pol. Fish. (2013b) 21: 129142.

109. Zabric D (2003). Enodnevnice-Ephemeroptera. V: Sket B. in sod. (ur.). Živalstvo Slovenije. Tehniška založba Slovenije. Bia: 276-280.

110. Zitek A, Schmutz S \& Jungwirth M (2004). Fischökologisches Monitoring an den Flüssen Pielach, Melk und Mank - im Rahmen des Eu-LIFE Projektes "Lebensraum Huchen" - Final Report. 113.

111. Zitek A, Haidvogl G, Jungwirth M, Pavlas P, Schmutz $S$ (2007). Ein ökologisch strategischer Leitfaden zur Wiederherstellung der Durchgängigkeit von Fließgewässern für die Fischfauna in Österreich. AP5 des MIRR-Projektes, Endbericht. Studie im Auftrag von Lebensministerium und Land Niederösterreich. $138 \mathrm{~S}$.

112. Zitek A, Schmutz S, Jungwirth M (2008). Assessing the efficiency of connectivity measures with regard to the EU-Water Framework Directive in a Danube-tributary system -Hydrobiologia 609:139-161. 